\title{
Hypothiocyanite and Hypothiocyanite/Lactoferrin Mixture Exhibit Virucidal Activity In Vitro against SARS-CoV-2
}

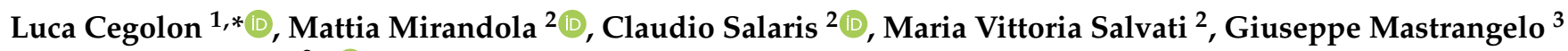 \\ and Cristiano Salata $2, *$ (D) \\ 1 Public Health Department, Local Health Unit N.2 "Marca Trevigiana", 31100 Treviso, Italy \\ 2 Department of Molecular Medicine, University of Padova, 35121 Padova, Italy; \\ mattia.mirandola@gmail.com (M.M.); claudio.salaris@studenti.unipd.it (C.S.); \\ mariavittoria.salvati@phd.unipd.it (M.V.S.) \\ 3 Department of Cardiac, Thoracic, Vascular Sciences \& Public Health, University of Padova, 35121 Padova, \\ Italy; giuseppe.mastrangelo@unipd.it \\ * Correspondence: 1.cegolon@gmail.com (L.C.); cristiano.salata@unipd.it (C.S.); \\ Tel.: +39-(0)4-9827-2364 (L.C. \& C.S.); Fax: +39-(0)4-9827-2355 (L.C. \& C.S.)
}

Citation: Cegolon, L.; Mirandola, M. Salaris, C.; Salvati, M.V.; Mastrangelo G.; Salata, C. Hypothiocyanite and Hypothiocyanite/Lactoferrin Mixture Exhibit Virucidal Activity In Vitro against SARS-CoV-2. Pathogens 2021, 10, 233. https://doi.org/10.3390/ pathogens 10020233

Received: 14 January 2021

Accepted: 17 February 2021

Published: 19 February 2021

Publisher's Note: MDPI stays neutral with regard to jurisdictional claims in published maps and institutional affiliations.

Copyright: (c) 2021 by the authors. Licensee MDPI, Basel, Switzerland. This article is an open access article distributed under the terms and conditions of the Creative Commons Attribution (CC BY) license (https:/ / creativecommons.org/licenses/by/ $4.0 /)$.

\begin{abstract}
SARS-CoV-2 replicates efficiently in the upper airways during the prodromal stage, resulting in environmental viral shedding from patients with active COVID-19 as well as from asymptomatic individuals. There is a need to find pharmacological interventions to mitigate the spread of COVID-19. Hypothiocyanite and lactoferrin are molecules of the innate immune system with a large spectrum cidal activity. The Food and Drug Administration and the European Medicines Agency designated the hypothiocyanite and lactoferrin combination as an orphan drug. We report an in vitro study showing that micromolar concentrations of hypothiocyanite exhibit dose- and time-dependent virucidal activity against SARS-CoV-2 and that the latter is slightly enhanced by the simultaneous presence of lactoferrin.
\end{abstract}

Keywords: hypothiocyanite; lactoferrin; lactoperoxidase system; ALX-009; SARS-CoV-2; COVID-19

\section{Introduction}

SARS-CoV-2 enters target cells binding the angiotensin-converting enzyme 2 (ACE2) receptor, widely expressed in human airways, particularly by epithelial cells of the nasal cavity and type II pneumocytes of the lung alveoli [1,2]. COVID-19 physiopathology can be classified into three clinical stages, depending on the main site of the infection [3]. At the initial asymptomatic stages, SARS-CoV-2 infection is predominantly located in the nasal cavity, where it elicits a contained local innate immune response. In the second mild symptomatic stage, COVID-19 mainly affects the pseudostratified epithelium of the upper respiratory tract, which can recover because the basal cells are spared. However, COVID-19 may cause a more severe reaction in the smaller branches of the bronchial airways, where club cells are likely infected. In the third life-threatening stage, SARS-CoV-2 spreads into the pulmonary alveoli by infecting type II pneumocytes expressing the ACE2 receptor.

Whilst treatment options for critically ill COVID-19 patients requiring hospitalization are now available, with corticosteroids emerging as the most effective one [4], there is a noteworthy lack of effective remedies against mild to moderate disease. It is believed that treatments with few adverse effects and that are easy to administer in outpatient settings, combined with an effective vaccine, could end the ongoing COVID-19 pandemic [5]. Molecules derived from the innate immune system, such as hypothiocyanite $\left(\mathrm{OSCN}^{-}\right.$; structural formula ${ }^{-} \mathrm{O}-\mathrm{S}-\mathrm{C} \equiv \mathrm{N}$ ) and lactoferrin (LF), represent promising candidates due to their broad-spectrum antimicrobial and antiviral activity [6,7].

Interestingly, Alaxia SAS has recently developed a solution of the above two molecules combined (ALX-009) for the treatment of bacterial infections in cystic fibrosis patients [8]. 
The solution was easily administered by inhalation of aerosol in a phase I clinical trial (NCT02598999 of 2018) to healthy volunteers and patients affected by cystic fibrosis. The combination of $\mathrm{OSCN}^{-}$and LF had already been designated as an orphan drug for treatment of cystic fibrosis by the US Food and Drug Administration and the European Medicines Agency in May 2009 [9]. It is conceivable that aerosol topical administration of $\mathrm{OSCN}^{-}$and LF combined might effectively inactivate free SARS-CoV-2 virions nearing the epithelium from outside or the ones being released from infected cells, thus mitigating or preventing the spread of the infection in the host tissues as well as its propagation to further susceptible individuals.

In view of the above, we conducted a study with the aim of testing the in vitro virucidal activity of $\mathrm{OSCN}^{-}$and of a combination of $\mathrm{OSCN}^{-}$and LF.

\section{Results}

\section{Virucidal Activity of $\mathrm{OSCN}^{-}$and $\mathrm{OSCN}^{-} / \mathrm{LF}$}

The virucidal activity of $\mathrm{OSCN}^{-}$was firstly investigated using a recombinant vesicular stomatitis virus (rVSV), encoding the reported gene luciferase instead of the viral glycoprotein. The rVSV can be easily manipulated under biosafety level 2 conditions and pseudotyped by the S protein (rVSV-S). The tropism of the rVSV-S is dictated by the heterologous $S$ envelope, and it represents an excellent surrogate of SARS-CoV-2 to study the virus entry and the viral neutralization [10-12]. The rVSV-S was therefore incubated with different $\mathrm{OSCN}^{-}$concentrations for $60 \mathrm{~min}$ at $37^{\circ} \mathrm{C}$ (preincubation), and then Vero cells were infected at multiplicity of infection (MOI) 0.065 and $0.015 \mathrm{FFU} /$ cell. Sixteen hours post-infection, cells were lysed and the luciferase expression was evaluated as a measure of viral infection. As shown in Figure 1a, viral infection was inhibited in a dose-dependent manner with $4.64 \mu \mathrm{M}$ as the concentration capable of reducing the viral infectivity by $50 \%\left(\mathrm{IC}_{50}\right)$ at the higher MOI. Moreover, more than $80 \%$ of rVSV-S infection was inhibited at the lower MOI. When performing the infection at the MOI $0.015 \mathrm{FFU} / \mathrm{mL}$, it became evident that the efficacy of the virucidal activity of $\mathrm{OSCN}^{-}$was also time-dependent in all conditions tested (preincubation: 60, 40, and $20 \mathrm{~min}$; without preincubation ( $0 \mathrm{~min}$ ) adding $\mathrm{OSCN}^{-}$during the infection of target cells) (Figure 1b). In particular, when the rVSV-S was incubated with $\mathrm{OSCN}^{-}$before the infection, we observed a reduction of the viral infectivity of more than $50 \%$ up to the concentration of $6.25 \mu \mathrm{M}$ (Figure $1 \mathrm{~b}$ ). Without preincubation ( $0 \mathrm{~min}$ ), a reduction of virus infectivity higher than $50 \%$ was observed starting from $\mathrm{OSCN}^{-}$ concentration of $12.5 \mu \mathrm{M}$.

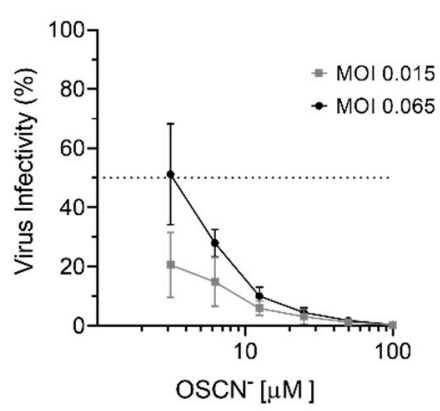

(a)

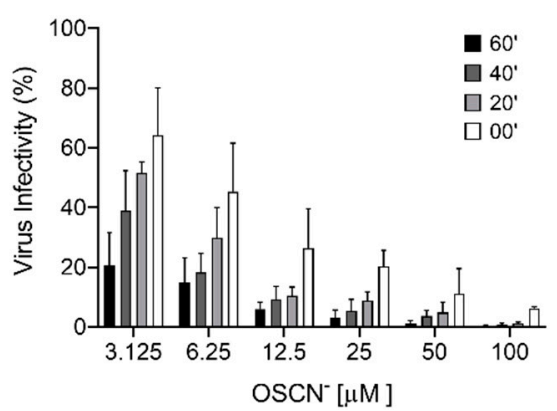

(b)

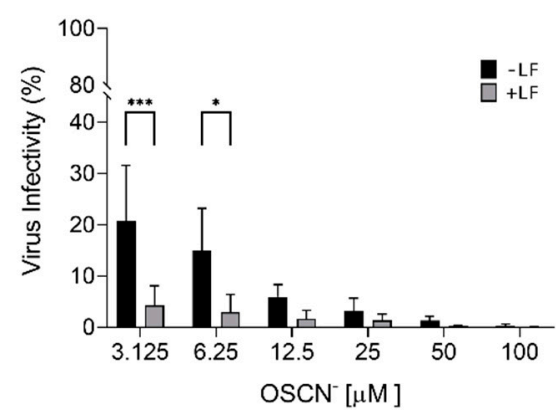

(c)

Figure 1. $\mathrm{OSCN}^{-}$and $\mathrm{OSCN}^{-} / \mathrm{LF}$ virucidal activity against the pseudovirus VSV-S diluted in Minimum Essential Medium (MEM). Infection of Vero cells was evaluated measuring the activity of the VSV-S encoded luciferase. (a) Efficiency of pseudovirus infection at MOI 0.065 and $0.015 \mathrm{FFU} / \mathrm{mL}$ after preincubation with different $\mathrm{OSCN}^{-}$concentrations for $1 \mathrm{~h}$ at $37^{\circ} \mathrm{C}$; (b) evaluation of the virucidal activity of $\mathrm{OSCN}^{-}$after pseudovirus treatment for $0,20,40$, and 60 min at $37^{\circ} \mathrm{C}$ before the infection of target cells at MOI 0.015; (c) comparison between $\mathrm{OSCN}^{-}$and $\mathrm{OSCN}^{-}+$LF virucidal activity after $1 \mathrm{~h}$ of preincubation of VSV-S and before cell infection at MOI 0.015. Data (mean $\pm \mathrm{SD}, \mathrm{N}=3$, experiments in duplicate) are percentages of no drug, set as $100 \%\left(^{*}=p<0.05 ;{ }^{* * *}=p<0.001\right)$. 
We also investigated the virucidal activity of $\mathrm{OSCN}^{-}$and LF combined. Preliminary experiments with LF showed that concentrations higher than $1 \mathrm{~g} / \mathrm{L}$ were required to inhibit the viral infection (data not shown). Therefore, we selected a concentration of $4 \mathrm{~g} / \mathrm{L}$ that was close to that previously used with $\mathrm{OSCN}^{-}$in ALX-009 against bacteria [8]. The combination $\mathrm{OSCN}^{-} / \mathrm{LF}$ significantly increased the virucidal activity despite using lower doses of $\mathrm{OSCN}^{-}$, achieving an inhibition of viral infection $>90 \%$ in comparison to $80-85 \%$ with $\mathrm{OSCN}^{-}$alone (Figure 1c) or $25 \%$ with LF alone (data not shown). These data suggest that, in our experimental conditions, $\mathrm{OSCN}^{-}$is the main virucidal agent, whereas at lower concentrations of $\mathrm{OSCN}^{-}$the presence of $\mathrm{LF}$ improves virus inactivation. As the addition of $\mathrm{OSCN}^{-}$and LF was not toxic to Vero cells, as shown by the outcome of the test for metabolic activity (MTT) conducted $24 \mathrm{~h}$ after their exposure to both reagents, we concluded that the inhibition of the viral infectivity was due to the ability of both compounds to interfere with the capacity of the virus to infect cells (Figure 2).

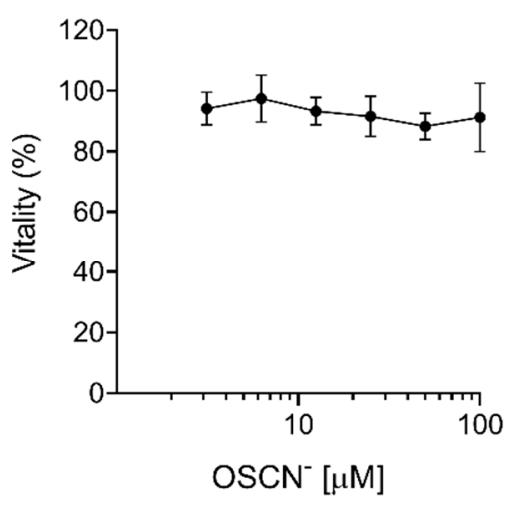

(a)

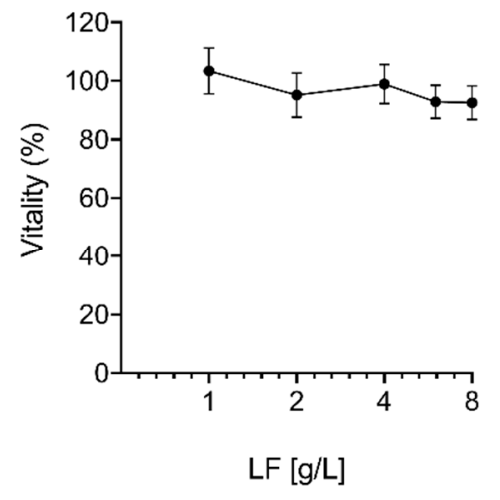

(b)

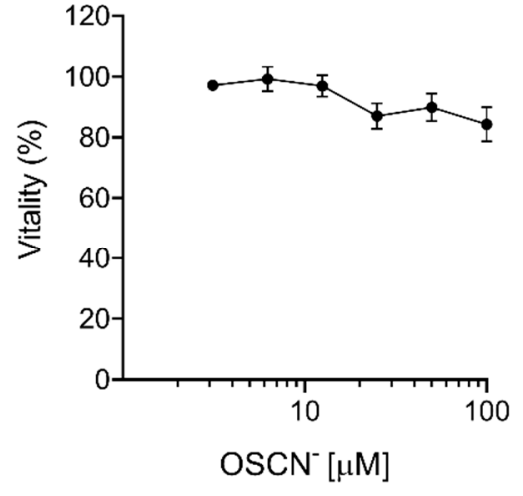

(c)

Figure 2. Cytotoxicity of $\mathrm{OSCN}^{-}$and LF. The cytotoxicity of (a) $\mathrm{OSCN}^{-}$, (b) LF, and (c) $\mathrm{OSCN}^{-}+\mathrm{LF}(4 \mathrm{~g} / \mathrm{L})$ diluted in MEM was evaluated on Vero cells after $24 \mathrm{~h}$ of treatment using the MTT assay. Data (mean $\pm \mathrm{SD}, \mathrm{N}=3$, experiments in quadruplicate) are percentages of no drug, set as $100 \%$.

Finally, we verified the virucidal activity of $\mathrm{OSCN}^{-}$and $\mathrm{OSCN}^{-} / \mathrm{LF}$ displayed against the VSV-S by using the real SARS-CoV-2. After virus-compound incubation for $60 \mathrm{~min}$, 10-fold dilutions of virus-compound mix were inoculated onto Vero-E6 cells (used for virus isolation and propagation) and the reduction of plaque generation was evaluated. Results confirmed the dose-dependent virucidal activity of $\mathrm{OSCN}^{-}\left(\mathrm{IC}_{50} \sim 11 \mu \mathrm{M}\right)$ and demonstrated that higher doses of $\mathrm{OSCN}^{-}$were required to inhibit SARS-CoV-2 infection with an incubation of 20 min (Figure 3a,b). In contrast to rVSV-S, the LF enhancement of the virucidal activity of $\mathrm{OSCN}^{-}$was significantly less pronounced for SARS-CoV-2 (Figure 3c).

Overall, our results indicate that $\mathrm{OSCN}^{-}$has a virucidal activity against SARS-CoV-2, and that the combination of $\mathrm{OSCN}^{-} / \mathrm{LF}$ slightly improved the virucidal effect of $\mathrm{OSCN}^{-}$. 


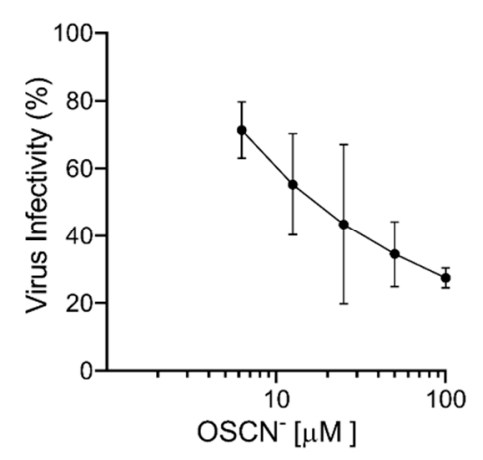

(a)

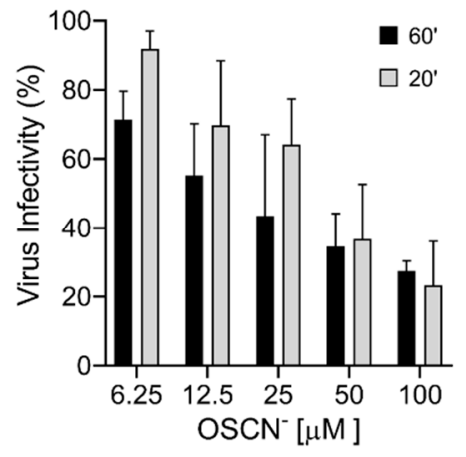

(b)

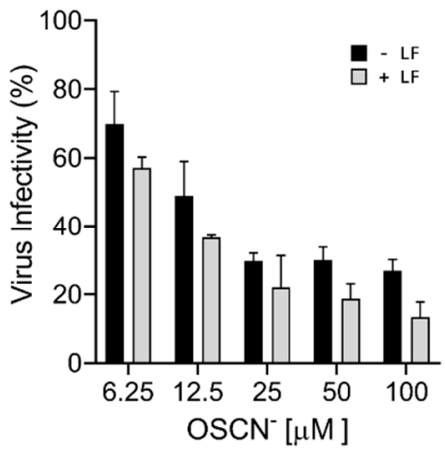

(c)

Figure 3. Virucidal activity of $\mathrm{OSCN}^{-}$and $\mathrm{OSCN}^{-} / \mathrm{LF}$ against SARS-CoV-2. SARS-CoV-2 was diluted in MEM and incubated for $1 \mathrm{~h}$ at $37^{\circ} \mathrm{C}$ with only OSCN${ }^{-}$or supplemented with LF before infection of Vero-E6 cells. The reduction of infectivity was evaluated by plaque assay. (a) Virucidal effect of $\mathrm{OSCN}^{-}$; (b) comparison between different times of virus-OSCN ${ }^{-}$exposure on the efficiency of the virucidal activity; (c) evaluation of the combination $\mathrm{OSCN}^{-}+\mathrm{LF}$ on the virucidal activity. Data (mean $\pm \mathrm{SD}, \mathrm{N}=3$, experiments in duplicate) are percentages of no drug, set as $100 \%$.

\section{Discussion}

We evaluated the virucidal activity of $\mathrm{OSCN}^{-}$and $\mathrm{OSCN}^{-} / \mathrm{LF}$ mixture against SARS$\mathrm{CoV}-2$. In our experimental conditions, $\mathrm{OSCN}^{-}$had evident in vitro virucidal effect against SARS-CoV-2.

Three components are mixed in the airway lumen to produce the biocidal compound $\mathrm{OSCN}^{-}$: lactoperoxidase (LPO), secreted by the serous cells of the submucosal glands and by goblet cells; the thiocyanate anion $\left(\mathrm{SCN}^{-}\right)$, delivered by the duct cells of submucosal gland; and hydrogen peroxide $\left(\mathrm{H}_{2} \mathrm{O}_{2}\right)$, released by epithelial cells [13]. Unlike in the trachea, in the main (third- and fifth-generation) bronchi, LPO mRNA was nearly absent in the lung parenchyma, suggesting lack of OSCN ${ }^{-}$production in the alveoli [14]. Furthermore, due to the need to enhance gas exchange, epithelial alveolar cells cannot contain strong protective structures and hence are weak, fragile, and more vulnerable to viral attacks. Since the biocidal effect of $\mathrm{OSCN}^{-}$takes place in the airway lumen, the aerosol administration of $\mathrm{OSCN}^{-}$may increase the inactivation of viral particles in compartments of the respiratory tract lacking endogenous $\mathrm{OSCN}^{-}$synthesis. Of course, only an in vivo study can validate our hypothesis by evaluating the antiviral efficacy in appropriate animal models.

Despite strong evidence of SARS-CoV-2 inactivation, the exact virucidal mechanism of $\mathrm{OSCN}^{-}$is still unknown. Ozone at high doses has been shown to inactivate SARS-CoV-2 by oxidative stress through ozone decomposition products and oxidation of double bonds of viral lipids, proteins, and amino acids, leading to the formation of reactive radicals $(\mathrm{RCOO}-)[15,16]$. Indirect modes of action further propagate the oxidation through a chain reaction [17]. Enveloped viruses-such as vesicular stomatitis Indiana virus, vaccinia virus, influenza A virus, and certain strains of type 1 herpes simplex virus-are more sensitive to ozone, whereas non-enveloped adenovirus type 2 was more resistant to this gas $[18,19]$. It is therefore plausible that irreversible oxidative damage of the lipid components of the viral envelope or of the nucleoproteins could also be the mechanism of virucidal activity against SARS-CoV-2 of OSCN ${ }^{-}$, which is a less potent (but also less damaging) oxidizing agent than ozone. As already shown, $\mathrm{LPO}$ yields $\mathrm{OSCN}^{-}$in the presence of $\mathrm{SCN}^{-} ; \mathrm{OSCN}^{-}$ in turn reacts with the thiol moiety of peptides or proteins (R-SH) generating sulfenyl thiocyanate (R-S-SCN), which, upon addition of one molecule of $\mathrm{H}_{2} \mathrm{O}$, produces sulfenic acid (R-S-OH) as well as regenerating $\mathrm{SCN}^{-}$at the end of the cycle [6]. The LPO cycle thus extends the duration of effects of $\mathrm{OSCN}^{-}$beyond the limited half-life (about $1 \mathrm{~h}$ ) of this compound, increasing the efficacy of its antiviral activity over time [20]. Sulphydryl oxidation determines inhibition of numerous enzymes containing the amino acid cysteine, abundant in coronavirus spike proteins, which are an excellent target for the inactivating 
activity of $\mathrm{OSCN}^{-}$[17]. This mechanism of action could partially explain the difference of $\mathrm{IC}_{50}$ values obtained with the pseudovirus and SARS-CoV-2. Since the amount of rVSV-S particles used in our experimental setting was lower $\left(4 \times 10^{4} \mathrm{FFU}\right)$ than the amount of SARS-CoV-2 particles $\left(1 \times 10^{5} \mathrm{PFU}\right)$, the inactivating effect of $\mathrm{OSCN}^{-}$on rVSV-S was stronger as compare to SARS-CoV-2.

The OSCN ${ }^{-}$concentration used in our experimental conditions was up to $100 \mu \mathrm{M}$, higher than that reported in human saliva $(20-60 \mu \mathrm{M})$ or in resting $(31 \mu \mathrm{M})$, stimulated whole saliva $(25 \mu \mathrm{M})$, and parotid saliva $(30 \mu \mathrm{M})[21,22]$. Our data suggested that physiological $\mathrm{OSCN}^{-}$concentrations could inhibit at least $50 \%$ of SARS-CoV-2 infection. However, $\mathrm{OSCN}^{-}$and bovine LF concentrations in ALX-009 were remarkably higher than those used in our experimental setting, reaching values of $3500 \mu \mathrm{M}$ and $8 \mathrm{~g} / \mathrm{L}$, respectively, which therefore should likely maximize their respective virucidal activity [8].

We have previously demonstrated that $\mathrm{OSCN}^{-}$inhibits A(H1N1)pdm09 influenza virus infection, as a similar $\mathrm{IC}_{50}$ than that observed for rVSV-S was obtained when the virus was challenged with $\mathrm{OSCN}^{-}$for $60 \mathrm{~min}$ at $37^{\circ} \mathrm{C}$ before infection [23]. Thereafter, the antiviral activity of $\mathrm{OSCN}^{-}$was also tested against several other types of influenza virus, confirming a strain-independent virucidal effect [24,25]. The higher $\mathrm{IC}_{50}$ of SARS-CoV-2 in comparison to influenza viruses does not necessarily imply a lower susceptibility to $\mathrm{OSCN}^{-}$, but may depend on different experimental settings. Thus, the $\mathrm{IC}_{50}$ values reported by studies that have used different viral loads, $\mathrm{OSCN}^{-}$/virus concentrations, and media might not be directly comparable. However, the overall results indicate a potent and potentially wide range of antiviral activity of $\mathrm{OSCN}^{-}$against respiratory viruses.

LF, one of the most abundant antimicrobial proteins occurring in normal airway secretions [26,27], seems to improve the inhibition of the viral infection only at lower $\mathrm{OSCN}^{-}$concentrations. The antiviral mechanism of LF is based on the ability to prevent the virus from anchoring targeted cells [28]. In particular, LF binds with heparan sulfate proteoglycans (HSPGs), which are cell-surface and extracellular matrix macromolecules acting as an attachment factor for many viruses including SARS-CoV-1. LF blocks the infection of SARS-CoV-1 by competing with the virus for HSPGs, therefore preventing the virus from binding to the surface of target cells [28]. Moreover, it has been shown that LF can partially inhibit SARS-CoV-2 infection in Caco-2 cells preincubated for three hours before the infection [29]. However, in our experimental conditions, it was difficult to detect the antiviral activity of LF, as this requires a longer time of exposure to target cells. Different experimental conditions could allow a better evaluation of the LF effect on SARS-CoV-2 infection, with and without the simultaneous presence of $\mathrm{OSCN}^{-}$. We can, though, speculate that LF may contribute to the antiviral activity: while $\mathrm{OSCN}^{-}$inactivates the viral particles, LF prevents the virus from binding to target cells.

In conclusion, our results indicate that $\mathrm{OSCN}^{-}$has a virucidal activity against SARS$\mathrm{CoV}-2$, and LF might increase its antiviral efficacy. Although the in vitro findings require an in vivo validation, the $\mathrm{LF}$ and $\mathrm{OSCN}^{-}$combination may have a relevant clinical impact by reducing the diffusion of infection in the host tissues as well as the spread of SARS-CoV-2 particles to new susceptible hosts. Given its proven broad-spectrum virucidal activity, $\mathrm{OSCN}^{-}$may turn out to be beneficial also against the emerging variants of SARS-CoV-2.

\section{Materials and Methods}

\subsection{Cell Culture and Viruses}

Vero (African green monkey kidney cells, ATCC ${ }^{\circledR}$ CCL-81), Vero E6 (ATCC ${ }^{\circledR}$ CRL1586), and HEK293T (ATCC ${ }^{\circledR}$ CRL-11268TM) cells were grown in Dulbecco's modified Eagle's medium (D-MEM) containing 10\% heat-inactivated fetal bovine serum (FBSi). Cells were maintained in a $5 \% \mathrm{CO}_{2}$ incubator at $37^{\circ} \mathrm{C}$, routinely checked for mycoplasma and confirmed negative. Culture medium and FBSi were obtained from Gibco (Thermofisher, Italy).

SARS-CoV-2 (Genbank: MW000351) and the rVSV $\Delta$ G-Luc, a recombinant vesicular stomatitis virus containing the gene encoding for the luciferase protein in place of the VSV-G gene [12], were used in the experiments. 


\subsection{Virus Stock Preparation and Titration}

Vero E6 cells were seeded in T175 flasks and then infected with SARS-CoV-2 at the multiplicity of infection (MOI) of $\sim 0.1$. At $72-96 \mathrm{~h}$ post-infection (p.i.), supernatants were collected, centrifuged at $2300 \mathrm{rpm}$ for $10 \mathrm{~min}$, then stored in aliquots at $-80^{\circ} \mathrm{C}$. Viral titer was determined by plaque assay on Vero E6 cells seeded on 24-well plates. Tenfold virus dilutions were prepared in DMEM and inoculated on confluent Vero-E6 cells for $1 \mathrm{~h}$ at $37^{\circ} \mathrm{C}$. Thereafter, virus inoculum was removed from each well and cells were overlaid with $300 \mu \mathrm{L}$ of $0.6 \%$ carboxymethylcellulose (Merck, Italy) diluted in DMEM supplemented with $2 \%$ FBSi. Seventy-two hours p.i., cells were fixed adding $300 \mu \mathrm{L}$ of $5 \%$ formaldehyde (Merck, Italy) in PBS $1 \times$ for $30 \mathrm{~min}$ at room temperature. Then, cells were stained with crystal violet in $20 \%$ ethanol. Virus titer was measured as plaque-forming units per milliliter $(\mathrm{PFU} / \mathrm{mL})$ based on the plaques formed in cell culture upon infection. All studies with viable SARS-CoV-2 were performed in the certified BSL3 laboratory.

For SARS-CoV-2-pseudotyped VSV production (rVSV-S), HEK293T cells were seeded in T175 flasks and then transfected by calcium phosphate-DNA precipitation with $40 \mu \mathrm{g}$ of pSARS-CoV-2-spike plasmid. After $24 \mathrm{~h}$, cells were infected with the rVSV $\Delta \mathrm{G}$-Luc virus at MOI 4 fluorescent focus-forming units (FFU)/cell. Sixteen hours p.i., cell culture supernatants were harvested and cell debris were cleared by centrifugation (2300 rpm for $7 \mathrm{~min}$ at $4{ }^{\circ} \mathrm{C}$ ). Thereafter, virus particles were pelleted by ultracentrifugation on a $20 \% \mathrm{p} / \mathrm{v}$ a sucrose cushion $\left(27,000 \mathrm{rpm}\right.$ for $150 \mathrm{~min}$ at $4{ }^{\circ} \mathrm{C}$ ) in a Beckmann (Beckman Coulter Italia, Italy) SW 28 Ti swinging-bucket rotor. Pellets were resuspended in $1 \mathrm{~mL}$ of ice-cold PBS1X/tube and mixed. Subsequently, the virus was aliquoted and stored at $-80{ }^{\circ} \mathrm{C}$ until use.

Titration of virus was determined by immunofluorescence on Vero cells seeded on 96-well plates. Viral stock was 10-fold serially diluted in DMEM and inoculated on confluent Vero cells for $1 \mathrm{~h}$ at $37^{\circ} \mathrm{C}$. Cells were then washed and DMEM supplemented with $10 \% \mathrm{FBSi}$ was added. After $18 \mathrm{~h}$, cells were fixed with precooled methanol-acetone for $1 \mathrm{~h}$ at $-20{ }^{\circ} \mathrm{C}$. Immune staining was performed by incubation with 1:3000 anti-VSV-M monoclonal antibody (Kerafast, Boston, MA, USA) on the infected cells for $90 \mathrm{~min}$ at $37^{\circ} \mathrm{C}$, followed by incubation with 1:1000 anti-rabbit Alexa Fluor ${ }^{\circledR} 488$ (Thermo Fisher Scientific, Italy) for $60 \mathrm{~min}$ at $37^{\circ} \mathrm{C}$. The fluorescent foci in each well were counted and viral titer was expressed as $\mathrm{FFU} / \mathrm{mL}$ [30].

\subsection{Compounds Preparation and Cytotoxicity Assay}

$\mathrm{OSCN}^{-}$solution was prepared via enzymatic reaction with an automated equipment EOLEASE $^{\circledR}$ (manufactured by Alaxia SAS, Lyon, France), obtaining an enzyme-free $\mathrm{OSCN}^{-}$ solution at $3500 \pm 10 \% \mu \mathrm{M}$ in phosphate buffer $\left(\mathrm{Na}_{2} \mathrm{HPO}_{4} / \mathrm{KH}_{2} \mathrm{PO}_{4}\right)$ at $\mathrm{pH} 7.5 \pm 0.1$. The $\mathrm{OSCN}^{-}$was extemporaneously produced via a two-step biocatalytic pathway (Figure 4). The enzyme-free $\mathrm{OSCN}^{-}$solution was then obtained by removing the enzymes from the mixture through a single-use dialysis micromodule (ultrafiltration membrane to eliminate enzymes) to obtain the enzyme-free $\mathrm{OSCN}^{-}$solution in a prefilled removable container. Due to its intrinsic reactivity, each solution freshly prepared was used alone or combined with lactoferrin within 15 min after preparation. Alaxia SAS provided reagents for the $\mathrm{OSCN}^{-}$production.

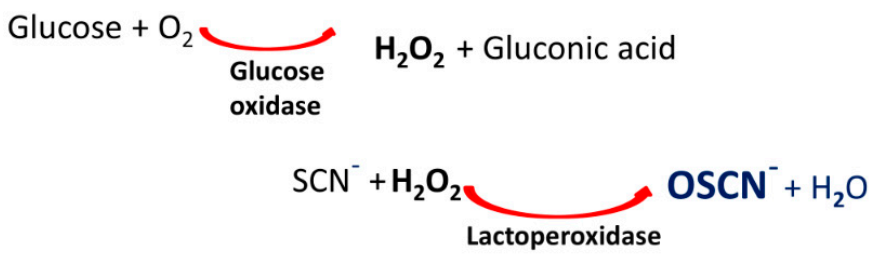

Figure 4. $\mathrm{OSCN}^{-}$extemporaneous production via a two-step biocatalytic pathway. 
Pharma-grade lyophilized lactoferrin (purity $>98 \%$ ) was made available by Alaxia SAS, as sterile vials. Lyophilized lactoferrin was reconstituted as solution with $0.9 \%$ sodium chloride solution at $10 \mathrm{~g} / \mathrm{L}$.

Compound dilutions for virus treatment were performed in Minimum Essential Media (MEM) purchased by Gibco (Thermofisher, Italy).

Cytotoxicity of OSCN ${ }^{-}$and LF was determined on Vero and Vero-E6 cells after $24 \mathrm{~h}$ of treatment. Cell viability was tested with an assay based on the reduction of a tetrazolium salt (MTT Cell Proliferation Assay, Thermofisher, Italy) in a 96-well plate format according to the manufacturer's instructions.

\subsection{Virucidal Assay}

To evaluate the $\mathrm{OSCN}^{-}$and LF virucidal activity, $4 \times 10^{4} \mathrm{FFU}$ of rVSV-S were incubated for $1 \mathrm{~h}$ at $37^{\circ} \mathrm{C}$ with $0-3.125-6.25-12.5-25-50$ and $100 \mu \mathrm{M}$ of $\mathrm{OSCN}^{-}$(final volume $350 \mu \mathrm{L}$ ) with or without $4 \mathrm{~g} / \mathrm{L}$ of LF. Positive control (mock sample) was treated with the solution used to prepare the $\mathrm{OSCN}^{-}$simulating the max $\mathrm{OSCN}^{-}$concentration. Next, Vero cells seeded on 96-well plates were infected for $1 \mathrm{~h}$ at $37^{\circ} \mathrm{C}$. Eighteen hours later, infection was evaluated measuring the relative light unit (RLU) with a VICTOR Multilabel Plate Reader (PerkinElmer Italia, Italy) using the Steady-Glo ${ }^{\circledR}$ Luciferase Assay System (Promega, Italy).

In the case of SARS-CoV-2, $1 \times 10^{5} \mathrm{PFU}$ were incubated for $1 \mathrm{~h}$ at $37^{\circ} \mathrm{C}$ with $0-6.25-$ 12.5-25-50 and $100 \mu \mathrm{M}$ of $\mathrm{OSCN}^{-}$(final volume $300 \mu \mathrm{L}$ ) with or without $4 \mathrm{~g} / \mathrm{L}$ of LF. Next, 10-fold virus dilutions were prepared in MEM and processed as above reported for the plaque assay. Viral titer was calculated for each sample and the virucidal activity was measured evaluating the efficiency of the infection in comparison to the mock treated control.

\subsection{Statistical Analysis}

All the experiments were performed in duplicate in at least three independent biological replicates. Statistical analysis was carried out with GraphPad Prism 8 software package (GraphPad Software, San Diego, CA, USA), employing the one-way ANOVA test. The threshold for statistical significance was $p<0.05$. All details on sample size and $p$ values for each experiment are provided in the relevant figure or its legend. Curve fitting was performed to determine $\mathrm{IC}_{50}$ values using a sigmoidal 4PL model in GraphPad Prism 8 software.

Author Contributions: L.C. and C.S. (Cristiano Salata) conceived the project and wrote the draft. C.S. (Cristiano Salata) propagated the SARS-CoV-2, performed experiments with SARS-CoV-2, provided reagents and facilities, and coordinated the project. C.S. (Claudio Salaris) performed experiments with SARS-CoV-2 and cell culture, collected and analyzed the data. M.M. and M.V.S. performed experiments with rVSV-S and cell culture, collected and analyzed the data. G.M. contributed to the initial conceptualization of the project, and helped with data interpretation. All authors have read and agreed to the published version of the manuscript.

Funding: This research was funded by University of Padova, grant number DOR-2019 and DOR-2020 to C.S. (Cristiano Salata). The APC was funded by University of Padova.

Institutional Review Board Statement: Not applicable.

Informed Consent Statement: Not applicable.

Data Availability Statement: Publicly available datasets were analyzed in this study. This data can be found here: http://researchdata.cab.unipd.it/---search for "Data referring to the paper: Hypothiocyanite and Hypothiocyanite/Lactoferrin Mixture Exhibit Virucidal Activity In Vitro against SARS-CoV-2".

Acknowledgments: We are grateful to Alaxia SAS, who provided protocols, equipment, and reagents to prepare $\mathrm{OSCN}^{-}$and LF. We thank Michael Whitt, University of Tennessee, Memphis, USA, for 
providing the VSV $\Delta$ G-Luc and Maria Rita Gismondo, L. Sacco University Hospital, Milan, Italy, for providing the SARS-CoV-2.

Conflicts of Interest: Authors did not accept honoraria or other payments from Alaxia SAS or other pharmaceutical industries. No other conflicts of interest have to be declared. The funders had no role in the design of the study; in the collection, analyses, or interpretation of data; in the writing of the manuscript, or in the decision to publish the results.

\section{References}

1. Salata, C.; Calistri, A.; Parolin, C.; Palù, G. Coronaviruses: A paradigm of new emerging zoonotic diseases. Pathog. Dis. 2019, 77. [CrossRef]

2. Yao, Y.; Wang, H.; Liu, Z. Expression of ACE2 in airways: Implication for COVID-19 risk and disease management in patients with chronic inflammatory respiratory diseases. Clin. Exp. Allergy 2020, 50, 1313-1324. [CrossRef]

3. Mason, R.J. Thoughts on the alveolar phase of COVID-19. Am. J. Physiol. Cell. Mol. Physiol. 2020, 319, L115-L120. [CrossRef]

4. Prescott, H.C.; Rice, T.W. Corticosteroids in COVID-19 ARDS: Evidence and Hope During the Pandemic. JAMA 2020, 324, 1292-1295. [CrossRef]

5. Kim, P.S.; Read, S.W.; Fauci, A.S. Therapy for Early COVID-19: A Critical Need. JAMA 2020, 324, 2149-2150. [CrossRef]

6. Cegolon, L. Investigating hypothiocyanite against SARS-CoV-2. Int. J. Hyg. Environ. Health 2020, 227, 113520. [CrossRef]

7. Cegolon, L.; Javanbakht, M.; Mastrangelo, G. Nasal disinfection for the prevention and control of COVID-19: A scoping review on potential chemo-preventive agents. Int. J. Hyg. Environ. Health 2020, 230, 113605. [CrossRef] [PubMed]

8. Tunney, M.M.; Payne, J.E.; McGrath, S.J.; Einarsson, G.G.; Ingram, R.J.; Gilpin, D.F.; Juarez-Perez, V.; Elborn, J.S. Activity of hypothiocyanite and lactoferrin (ALX-009) against respiratory cystic fibrosis pathogens in sputum. J. Antimicrob. Chemother. 2018, 73, 3391-3397. [CrossRef]

9. Moreau-Marquis, S.; Coutermarsh, B.; Stanton, B.A. Combination of hypothiocyanite and lactoferrin (ALX-109) enhances the ability of tobramycin and aztreonam to eliminate Pseudomonas aeruginosa biofilms growing on cystic fibrosis airway epithelial cells. J. Antimicrob. Chemother. 2015, 70, 160-166. [CrossRef]

10. Salata, C.; Calistri, A.; Alvisi, G.; Celestino, M.; Parolin, C.; Palù, G. Ebola Virus Entry: From Molecular Characterization to Drug Discovery. Viruses 2019, 11, 274. [CrossRef]

11. Nie, J.; Li, Q.; Wu, J.; Zhao, C.; Hao, H.; Liu, H.; Zhang, L.; Nie, L.; Qin, H.; Wang, M.; et al. Quantification of SARS-CoV-2 neutralizing antibody by a pseudotyped virus-based assay. Nat. Protoc. 2020, 15, 3699-3715. [CrossRef]

12. Whitt, M.A. Generation of VSV pseudotypes using recombinant $\Delta \mathrm{G}$-VSV for studies on virus entry, identification of entry inhibitors, and immune responses to vaccines. J. Virol. Methods 2010, 169, 365-374. [CrossRef]

13. Conner, G.E.; Salathe, M.; Forteza, R. Lactoperoxidase and Hydrogen Peroxide Metabolism in the Airway. Am. J. Respir. Crit. Care Med. 2002, 166, S57-S61. [CrossRef] [PubMed]

14. Gerson, C.; Sabater, J.; Scuri, M.; Torbati, A.; Coffey, R.; Abraham, J.W.; Lauredo, I.; Forteza, R.; Wanner, A.; Salathe, M.; et al. The Lactoperoxidase System Functions in Bacterial Clearance of Airways. Am. J. Respir. Cell Mol. Biol. 2000, 22, 665-671. [CrossRef]

15. Jay, R.R.; Howard, R. A Plausible "Penny" Costing Effective Treatment for Corona Virus-Ozone Therapy. J. Infect. Dis. Epidemiol. 2020, 6. [CrossRef]

16. Izadi, M.; Cegolon, L.; Javanbakht, M.; Sarafzadeh, A.; Abolghasemi, H.; Alishiri, G.; Zhao, S.; Einollahi, B.; Kashaki, M.; Jonaidi-Jafari, N.; et al. Ozone therapy for the treatment of COVID-19 pneumonia: A scoping review. Int. Immunopharmacol. 2021, 92, 107307. [CrossRef]

17. Tizaoui, C. Ozone: A Potential Oxidant for COVID-19 Virus (SARS-CoV-2). Ozone Sci. Eng. 2020, 42, 378-385. [CrossRef]

18. Gavazza, A.; Marchegiani, A.; Rossi, G.; Franzini, M.; Spaterna, A.; Mangiaterra, S.; Cerquetella, M. Ozone Therapy as a Possible Option in COVID-19 Management. Front. Public Health 2020, 8, 417. [CrossRef] [PubMed]

19. Murray, B.K.; Ohmine, S.; Tomer, D.P.; Jensen, K.J.; Johnson, F.B.; Kirsi, J.J.; Robison, R.A.; O'Neill, K.L. Virion disruption by ozone-mediated reactive oxygen species. J. Virol. Methods 2008, 153, 74-77. [CrossRef]

20. Ashby, M.T.; Kreth, J.; Soundarajan, M.; Sivuilu, L.S. Influence of a model human defensive peroxidase system on oral streptococcal antagonism. Microbiology 2009, 155, 3691-3700. [CrossRef]

21. Tenovuo, J. Clinical applications of antimicrobial host proteins lactoperoxidase, lysozyme and lactoferrin in xerostomia: Efficacy and safety. Oral Dis. 2002, 8, 23-29. [CrossRef] [PubMed]

22. Jalil, R.A. Concentrations of Thiocyanate and Hypothiocyanite in the Saliva of Young Adults. J. Nihon Univ. Sch. Dent. 1994, 36, 254-260. [CrossRef] [PubMed]

23. Cegolon, L.; Salata, C.; Piccoli, E.; Juarez, V.; Palu', G.; Mastrangelo, G.; Calistri, A. In vitro antiviral activity of hypothiocyanite against A/H1N1/2009 pandemic influenza virus. Int. J. Hyg. Environ. Health 2014, 217, 17-22. [CrossRef]

24. Patel, U.; Gingerich, A.; Widman, L.; Sarr, D.; Tripp, R.A.; Rada, B. Susceptibility of influenza viruses to hypothiocyanite and hypoiodite produced by lactoperoxidase in a cell-free system. PLoS ONE 2018, 13, e0199167. [CrossRef]

25. Gingerich, A.; Pang, L.; Hanson, J.; Dlugolenski, D.; Streich, R.; Lafontaine, E.R.; Nagy, T.; Tripp, R.A.; Rada, B. Hypothiocyanite produced by human and rat respiratory epithelial cells inactivates extracellular H1N2 influenza A virus. Inflamm. Res. 2015, 65, 71-80. [CrossRef] [PubMed] 
26. Singh, P.K.; Parsek, M.R.; Greenberg, E.P.; Welsh, M.J. A component of innate immunity prevents bacterial biofilm development. Nat. Cell Biol. 2002, 417, 552-555. [CrossRef] [PubMed]

27. Buonfiglio, L.G.V.; Borcherding, J.A.; Frommelt, M.; Parker, G.J.; Duchman, B.; Calderón, O.G.V.; Fernandez-Ruiz, R.; Noriega, J.E.; Stone, E.A.; Gerke, A.K.; et al. Airway surface liquid from smokers promotes bacterial growth and biofilm formation via iron-lactoferrin imbalance. Respir. Res. 2018, 19, 1-11. [CrossRef]

28. Lang, J.; Yang, N.; Deng, J.; Liu, K.; Yang, P.; Zhang, G.; Jiang, C. Inhibition of SARS Pseudovirus Cell Entry by Lactoferrin Binding to Heparan Sulfate Proteoglycans. PLoS ONE 2011, 6, e23710. [CrossRef] [PubMed]

29. Salaris, C.; Scarpa, M.; Elli, M.; Bertolini, A.; Guglielmetti, S.; Pregliasco, F.; Blandizzi, C.; Brun, P.; Castagliuolo, I. Protective Effects of Lactoferrin against SARS-CoV-2 Infection In Vitro. Nutrients 2021, 13, 328. [CrossRef] [PubMed]

30. Salata, C.; Baritussio, A.; Munegato, D.; Calistri, A.; Ha, H.R.; Bigler, L.; Fabris, F.; Parolin, C.; Palù, G.; Mirazimi, A. Amiodarone and metabolite MDEA inhibit Ebola virus infection by interfering with the viral entry process. Pathog. Dis. 2015, 73. [CrossRef] 